\title{
Multiple Intelligence Focusing on Practical Subjects among Final Year Students of School of Education, Universiti Teknologi Malaysia
}

\author{
Wan Nasrul Afiq Wan Nazri, Syafiqah Saidi, Nur Hazirah Noh Seth, Mohd Rasidi Pairan, \\ Hanifah Jambari, Nurul Aini Mohd Ahyan
}

\begin{abstract}
This study was conducted to identify the significant differences between female students and male students who took the workshop's practical subjects. Therefore, three objectives of the study are to identify the multiple intelligences among students, the dominant of multiple intelligence in the workshop's practical subjects and to identify the significant differences between multiple intelligences and the gender of the 4th year student from School of Education, Faculty of Social Science and Humanities, Universiti Teknologi Malaysia in the subject practical workshop. The design of this study is a descriptive study using quantitative data. In this study, the population identified consists of 204 4th year students of the School of Education, Faculty of Social Science and Humanities who attended the Bachelor of Technology with Education in Mechanical Engineering (SPPJ), Buildings (SPPQ), Electrical and Electronic (SPPR) and Living Skills (SPPH). A total of 180 samples were identified based on sampling formula and the instrument used was a set of questionnaire with reliability value of $\alpha=0.86$ which contained 48 items in part $B$ based on multiple intelligence and respondent demographic in part $A$. The study data was processed using Statistical Package for Social Sciences SPSS version 25 to get the results of the study in the form of descriptive analysis like percentage, frequency, mean score and standard deviation while inference analysis with independent $T$ test to find mean difference between gender. The findings show that each student has more than one intelligence for each respondent and the intelligence of Naturalist, Intrapersonal, Verbal Linguistics and Kinestatic Body is the dominant intelligence of the students. In addition, the findings showed that there was no significant difference between the multiple intelligences and the gender of the students. In conclusion, intelligence varies by individual and is unrelated to gender and intelligence can be enhanced through education and experience.
\end{abstract}

Keywords: Higher education multiple intelligence, practical, student

\section{INTRODUCTION}

Normally, society perceive human's mind similarly to the individual's level of intelligence. When someone achieves

Revised Manuscript Received on April 19, 2019. Technical and Vocational Education, Universiti Teknologi Malaysia, Skudai, Malaysia.

Shafiqah Binti Saidi, Master Student Department of Technical and Vocational Education, Universiti Teknologi Malaysia, Skudai, Malaysia.

Nur Hazirah Binti Noh@Seth, PhD holder in Mechanical Engineering and currently a researcher and educator in Universiti Teknologi Malaysia.

Mohd Rasidi Bin Pairan, PhD holder in Mechanical Engineering and currently a researcher and educator in Universiti Teknologi Malaysia.

Hanifah Binti Jambari, Senior lecturer at Department of Technical and Engineering Education, Faculty of Social Sciences and Humanities UTM, Johor, Malaysia.

Nurul Aini Binti Mohd Ayhan, senior lecturer at Department of Technical and Engineering Education, School of Education, Faculty of Social Sciences and Humanities UTM, Johor, Malaysia.
Wan Nasrul Afiq Bin Wan Nazri, Master Student Department of

success in intellectual field or a student who is brilliant and achieves 10 A's in Malaysian Certificate of Education or Sijil Pelajaran Malaysia (SPM), society assumes that the individual has a great mind and intelligent. This perception has been absorbed into the society that intelligence is concentrated on intelligence in studies [15]. This has caused many parents racing to send their children to top schools to improve their children's level of intelligence. They assume students who did not incline towards academic achievement are dropped out or failed. This is because, they did not know that an individual intelligence is comprised IQ, EQ, and SQ. Intelligence like EQ and SQ is given less exposure to the society especially parents that wanted their children to be successful in academic.

Therefore, there are many intelligence theories were introduced to determine individual intelligence such as intellectual quotient (IQ), emotional intelligence (EI, EQ), spiritual intelligence (SI, SQ), multiple intelligence (MI), managerial quotient (MQ), and successful intelligence. However, this study focuses on multiple intelligence and its relationship with students' gender in practical laboratory subject.

According [20], excellence is an individual's capability to use every potential that has been given by god. Excellence can be formed by an individual in improving multiple intelligence to obtain a critical and creative thinking mind. Usually, excellence is associated with students' academic which focuses on only a few intelligences such as verballinguistic intelligence and logical-mathematical intelligence [1]. This is because, the examinations that the students need to take are only emphasising on logical-mathematical and verbal-linguistic intelligences. Students need to understand question that is related to verbal-linguistic intelligence while the given problem that needs to be solved with thinking skill and formula application. This has caused students that perform less in academic to question whether it is because of their low level of intelligence or they have other intelligences that are higher? Therefore, there are a few factors that cause the improved achievement or students' excellence in studies. One of the important factors in students' achievement is students' level of intelligence [2]. Normally, excellent students have a high level of intelligence. According to Howard Gardner, an individual has eight types of intelligence in them and these intelligences are not depending on each other [18]. These 
intelligences can also be improved through proper activities and education [11]. Intelligence can also be improved with suitable activities to maximise the students' intelligence potential.

With respect to that, this study was carried out to identify different students' level of intelligence in practical laboratory subject and the dominant multiple intelligence in the fourth-year students of School of Education, Faculty of Social Sciences and Humanities, Universiti Teknologi Malaysia.

\section{A. $\quad$ Research Objectives And Questions}

This study aims to identify different students' level of intelligence for practical laboratory subject.

The objectives that need to be achieved in this study are:

1) To identify the multiple intelligence among the fourth-year students of School of Education, Faculty of Social Sciences and Humanities, UTM.

2) To identify the dominant multiple intelligence among the fourth-year students of School of Education, Faculty of Social Sciences and Humanities, UTM in laboratory subject.

3) To identify the significant difference between multiple intelligence and the gender of the fourth-year students of School of Education, Faculty of Social Sciences and Humanities, UTM in laboratory subject.

This study was carried out to answer a few research questions that were presented. The research questions are:

1) What is the multiple intelligence among the fourth-year students of School of Education, Faculty of Social Sciences and Humanities, UTM?

2) What is the dominant multiple intelligence among the fourth-year students of School of Education, Faculty of Social Sciences and Humanities, UTM in laboratory subject?

3) Is there any significant difference between multiple intelligence and the gender of the fourth-year students of School of Education, Faculty of Social Sciences and Humanities, UTM in laboratory subject?

The null hypothesis (H0) that was tested in this study is as follows:

There is no significant difference between multiple intelligence: verbal-linguistic, logical-mathematical, visualspatial, kinestatic-body, musical-rhythmic, interpersonal, intrapersonal, and naturalistic with the gender of the fourthyear students of School of Education, Faculty of Social Sciences and Humanities, UTM in laboratory subject.

\section{RESEARCH METHODOLOGY}

Research design functions as a guide in the aspects of collecting, analysing, and interpreting from the research that has been done. Research design is defined as the ways to carry out the research [14]. This research is a quantitative research which used score value, quantity, numbers and frequency. This study is a descriptive research which used questionnaires to obtain data from the sample. This study was carried out at the School of Education, Faculty of Social Sciences and Humanities, UTM, Johor and this research was more focused on the fourth-year students that have taken the laboratory subject.
The population of this study refers to the fourth-year students of School of Education, Faculty of Social Sciences and Humanities, UTM, Johor. The size of population in this study was about 204 students consisted of the students from SPPJ, SPPR, SPPQ, and SPPH courses which all of them are fourth-year students of School of Education, Faculty of Social Sciences and Humanities, UTM, Johor. To determine the accurate number of respondents, this study used the sampling formula [8]. This study involved 180 respondents from the initial quantity which was 204 fourth-year students of School of Education. The election of respondents was done by using the stratified random sampling method. This is because, the researcher wishes to obtain a uniform feedback. Simple random sampling method was done at every stratum to choose the sample. A set of questionnaires was used in this research containing two main sections, Section A which is the demography of the respondents and Section $B$ is based on multiple intelligence. The questionnaire used the 5-point Likert scale.

All data were collected, recorded and analysed using the SPSS version 25 software. The items on Section A were analysed using frequency and percentage scores of descriptive statistics. The items on Section B were analysed using frequency, percentage and mean scores. To observe the relationship of multiple intelligence on the gender of the fourth-year students of School of Education FSSK UTM, the researcher used the inferential statistics which used the dependent $t$ test to distinguish the mean between two genders. A pilot study was done on 30 students from the research population to determine the reliability of the items in the questionnaire. The obtained data was analysed using SPSS version 25 software to determine the Cronbach's Alpha value. The obtained Cronbach's Alpha value for all items was 0.86 and in the high level.

Table.1 Sample Sizes According to Courses

\begin{tabular}{|c|c|c|c|}
\hline COURSE & POPULATION & PERCENTAGE & SAMPLE \\
& $(\mathbf{N})$ & $(\boldsymbol{\%})$ & SIZE (s) \\
SPPJ & 67 & 36.4 & 57 \\
SPPR & 43 & 23.4 & 39 \\
SPPQ & 51 & 27.7 & 45 \\
SPPH & 43 & 23.4 & 39 \\
TOTAL & 204 & 100 & $\mathbf{1 8 0}$ \\
\hline
\end{tabular}

\section{DATA ANALYSIS}

From the findings of questionnaire feedback, majority of the respondents consisted of female students about $62.8 \%$ compared to the male students. Besides that, majority of the respondents were Malay with $93.3 \%$. Most of the respondents consisted of SPPJ course, $31.7 \%$ and the respondents in this study, majority of the students obtained cumulative grade point average (CGPA) between 3.50 and 4.00 about $83.9 \%$. 
From the analysis, there were fourth-year students of School of Education, Faculty of Social Sciences and Humanities, UTM that have high level of multiple intelligence on eight types of multiple intelligence. However, there were four types of multiple intelligence which were more dominant to the fourth-year students of School of Education, Faculty of Social Sciences and Humanities, UTM. The intelligences were naturalistic intelligence, intrapersonal intelligence, verbal-linguistic intelligence, and bodily-kinaesthetic intelligence. According to the findings of the research analysis, the null hypothesis is accepted, and no hypothesis is rejected in this study. The significant value from the dependent $t$ test was more than the value of $p>0.05$ and the hypothesis of this study is accepted which there is no significant difference between multiple intelligence and students' gender.

Table.2 Level of Multiple Intelligence of the Fourth-Year Students

\begin{tabular}{|c|c|c|c|c|}
\hline 1 & Verbal-linguistic & $\mathbf{4 . 4 3}$ & 0.637 & High \\
\cline { 3 - 4 } & & & \\
\hline 2 & Logical-mathematical & 4.27 & 0.698 & High \\
\hline 3 & Visual-spatial & 4.39 & 0.659 & High \\
\hline 4 & Bodily-kinaesthetic & $\underline{\mathbf{4 . 4 1}}$ & 0.573 & High \\
\hline 5 & Musical-rhythmic & 4.10 & 0.823 & High \\
\hline 6 & Interpersonal & 4.27 & 0.633 & High \\
\hline 7 & Intrapersonal & $\underline{\mathbf{4 . 4 4}}$ & 0.644 & High \\
\hline 8 & Naturalistic & $\underline{\mathbf{4 . 5 1}}$ & 0.479 & High \\
\hline
\end{tabular}

Table.3 Findings of the Independent $T$ Test of Multiple Intelligence with Gender

\begin{tabular}{|c|c|c|}
\hline $\boldsymbol{t}$ value & Significance level & Multiple Intelligence \\
\hline 1.314 & 0.190 & Verbal-linguistic \\
\hline 0.786 & 0.433 & Logical-mathematical \\
\hline 0.210 & 0.983 & Visual-spatial \\
\hline 0.869 & 0.386 & Bodily-kinaesthetic \\
\hline 0.760 & 0.448 & Musical-rhythmic \\
\hline 0.950 & 0.344 & Interpersonal \\
\hline 0.477 & 0.634 & Intrapersonal \\
\hline 0.540 & 0.957 & Naturalistic \\
\hline
\end{tabular}

\section{DISCUSSION}

The discussion was made based on the findings from the analysed items from the respondents' demography and research question which related to the eight types of multiple intelligence among the fourth-year students of School of Education, Faculty of Social Sciences and Humanities, UTM.

\section{A. Multiple Intelligence among the Fourth-Year Students}

The findings of this study show that the multiple intelligence of the fourth-year students of School of Education, Faculty of Social Sciences and Humanities was \begin{tabular}{|l|l|l|l|l|}
\hline No. & Multiple Intelligence & Mean & Standard deviation & Level \\
\hline
\end{tabular}

high for all types of intelligence. This is because, the experiences that they had from primary school to the university level which used and applied communication skills, the right usage of grammar, and good speech. Normally, students who continued to study at the university level are more dominant in this intelligence because they can highlight the use of language in presentation and writing report [16]. Besides that, the specialisation in engineering course is more dominant in the aspects of calculation, formula usage, specifying causes and effects of a product. From the researcher's opinion, the fourth-year students of School of Education can master the level of logicalmathematical intelligence well because they are exposed with the conversion of units and calculations during practical activities in the laboratory. The students also have improved in the logical-mathematical intelligence from the early school because the learning system is prioritising two types of intelligence [13].

Engineering field especially practical laboratory requires students to draw geometrical drawings and understand project drawings [4]. According to [9], the visual-spatial intelligence is important for learning and solving problems in engineering. Practical laboratory is a learning process which involves body movement to make a product or work and improves technical skills. According to [6], skills are improved knowledge from hands-on activities in the class. Musical-rhythmic intelligence is a normal occurrence in the students' life because they are surrounded by sounds which help in life such as the sound of nature like the sound of rain droplets. Therefore, the level of multiple intelligence of the fourth-year students were at high level because exposure to the elements of multiple intelligence unconsciously.

B. Dominant Multiple Intelligence Among the Fourthyear Students

The dominant intelligence among all types of intelligence are naturalistic intelligence, intrapersonal intelligence, verbal-linguistic intelligence, and bodily-kinaesthetic intelligence. The naturalistic intelligence has the highest mean value meanwhile the intrapersonal intelligence, verbal-linguistic intelligence, and bodily-kinaesthetic intelligence have a small and high difference of mean values. According to [5], every individual has all the multiple intelligence but to a degree or strength level and different skills. Therefore, there is an intelligence with higher rating or dominant because of the results from education, experience, and surroundings. These intelligences can be expanded through individual education, experience and surroundings [5]. Thus, the more dominant intelligence is caused by the experience and surroundings of the student from early exposure to the intelligence.

Verbal-linguistic intelligence is an important intelligence for a student because this intelligence improves communication and writing skills with the usage of good grammar. According to [7], communication is important in education industry because it is a medium in teaching and learning processes. Meanwhile, the naturalistic intelligence

Published By

Blue Eyes Intelligence Engineering 
has the highest mean value due to the students' experience since early schooling because they are educated to appreciate nature and have known a few types of flora and fauna. According to [3] experiences that are related to nature is the basics to environmental knowledge. Therefore, the naturalistic intelligence is more dominant in this study because the students were exposed to it earlier. Intrapersonal intelligence is an intelligence that shows the tendency to give attention to other people and like to give help to others. From the feature, it shows that the intrapersonal intelligence is very close to the features in the teaching profession. According to [19], intrapersonal skill is the main skill compared to ingenuity and personality in delivering lessons. As a student that currently in the field of teaching, students are equipped with required skills and basics for a teacher indirectly. Furthermore, the bodily-kinaesthetic intelligence is a dominant intelligence among the fourth-year students of School of Education. This is because, the stated intelligence is the individual ability to carry out work by using their body [10]. The fourth-year students of School of Education, Faculty of Social Sciences and Humanities, UTM are from technical and engineering courses which mainly use their body in performing practical learning.

Significant Difference in Multiple Intelligence on Gender Among the Fourth-year Students

In this study, the researcher has introduced a null hypothesis which used to test the significant difference of multiple intelligence with the gender of the fourth-year students of School of Education, Faculty of Social Sciences and Humanities, UTM. Overall, the null hypothesis which stated that no significant difference of multiple intelligence with students' gender is accepted.

This is because, the fourth-year students of School of Education, Faculty of Social Sciences and Humanities are future teacher graduates who require high verbal-linguistic intelligence. Therefore, the findings of this study show that there is no significant difference between the verballinguistic intelligence of male and female students. This study also contradicts with [12] which stated that female students are better in verbal-linguistic intelligence. Furthermore, there is no significant difference in logicalmathematical intelligence for the students from the engineering course which require logical-mathematical intelligence, because both male and female students need to solve the given problems and think logically. There is also no significant difference in visual-spatial intelligence and bodily-kinaesthetic intelligence for both male and female fourth-year students of School of Education. This is because, the students can describe shapes, space, and perform ideas in visual forms. Students taking engineering course are surely good in drawing shapes and geometry, because engineering requires product drawing in producing work [17]. Besides that, the fourth-year students of School of Education, Faculty of Social Sciences and Humanities, UTM are students from engineering course that will be teachers at Vocational College. Future Vocational College teacher must have skills related to body movements in carrying out practical work in laboratory.

\section{CONCLUSION}

From the conclusion in this study, every student has different level of intelligence and intelligence is not influenced by the background of students' demography such as age and gender, however, it is influenced by the experience that the students had went through. For example, there was no significant difference in bodily-kinaesthetic intelligence in male and female students because students have experienced in practical work at laboratory during diploma education. Intelligence can also be improved because intelligences can be expanded through individual education, experience, and surrounding [5]. Thus, teachers need to know students' level of intelligence before planning for teaching and learning sessions to expand students' intelligences without neglecting other intelligences.

\section{ACKNOWLEDGEMENT}

The authors would like to express their gratitude to the Ministry of Education and Universiti Teknologi Malaysia for the support in conducting this research under Fundamental Research Grant Scheme (FRGS) with vot.no R.J130000.7853.5F083.

\section{REFERENCES}

1. Siti Rahayah Ariffin, Roseni Ariffin HMZ. Faktor Kontribusi Kecerdasan Pelbagai dalam Kalangan Pelajar Remaja. Fakt Kontribusi Kecerdasan Pelbagai dalam Kalangan Pelajar Remaja J Pendidik. 2008.

2. Azizi Yahaya, Y. B. Kecerdasan Emosi dan Hubungannya Dengan Pencapaian Akedamik dan Tingkah Laku Pelajar. 2005.

3. Bogeholz, S. Nature Experience and its Importance for Environmental Knowlegde, Values and Action: Recent German Empirical Contributions. Environment Education Research, 12, 65-84.2006.

4. Broda, M. B. Multiple Intelligences. ESSAI: Vol 7, Article 13. 2009

5. Gardner H. Frames of Mind: The Theory of Multiple Intelligences (Google eBook). New York: Basic Books 1983.

6. Nor Hasniza Ibrahim JS dan, MustapaSharir MS KEFAHAMAN DAN TAHAP AMALAN PEMBELAJARAN SECARA KONTEKSTUAL DI KALANGAN GURU SAINS LUAR BANDAR Nor. Nurs Res. 1981;

7. Dazali NSM, Awang MI. Tahap kemahiran komunikasi dalam kalangan pelajar sarjana muda pendidikan IPTA di utara semenanjung Malaysia. J Pendidik Bhs Melayu. 2014;

8. Krejcie R V., Morgan DW. Determining Sample Size for Research Activities. Educ Psychol Meas. 1970.

9. Alias M, Black TR, Gray DE. Effect of instructions on spatial visualisation ability in civil engineering students International Education Journal. 2002.

10. Mohamad, F. Kecerdasan Kejayaan Dan Hubungannya Dengan Pencapaian Akademik Pelajar Kejuruteraan Universiti Tun Hussien Onn Malaysia: Tesis Sarajana. 2008

11. Noorhafiezah, Z. Kecerdasan Matematik-Logik Dalam Kalangan Pelajar Sarjana Pendidikan Teknik Dan Vokasional UTHM. 2013.

12. Noraini Idris. Pedagogi Dalam Pendidikan Matematik. 
Kuala Lumpur: Utusan Publications \& Distributors. 2001

13. Norfezlina, R..Pola Kecerdasan Pelbagai Dengan Pencapaian Akademik Bagi Pelajar Kimia Fakulti Sains UTM. Universiti Teknologi Malaysia: 2011

14. Sabitha, M. Kaedah Penyelidikan Sains Sosial. Petaling Jaya, Selangor: Pearson Prentice Hall. 2005

15. Ariffin SR, Ariffin R, Zin AM, Mohamed NNN. Faktor Kecerdasan Pelbagai dalam Pembentukan Profil Remaja. Malaysian J Learn Instr. 2011;

16. Ariffin SR, Subhan T, Meerah M, Othman N, Zin IM. ANALISIS KECERDASAN PELBAGAI (MULTIPLE INTELLIGENCES) DI KALANGAN PENSYARAH DI SEBUAH INSTITUSI PENGAJIAN TINGGI (IPT). J Teknol. 2004;

17. Sorby SA, Baartmans BJ. The Development and Assessment of a Course for Enhancing the 3-D Spatial Visualization Skills of First Year Engineering Students. J Eng Educ. 2000;

18. Syathirah, A. (2012, Mac). Kecerdasan Pelbagai Dalam Kalangan Pelajar BPSP UPM. Retrieved from Research Gate.net:https://www.researchgate.net/publication/26094 2697_KECERDASAN_PELBAGAI_DALAM_KALAN GAN_PELAJAR_BPSP_UPM

19. Syofia Ulfah, Zamri Mahamod, Jamaluddin Badusah, Hamidah Yamat. Amalan Komunikasi Interpersonal Direktif Guru Bahasa Indonesia Ketika Memulakan Pengajaran. J Pendidik Bhs Melayu - JPBM (Malay Lang Educ J - MyLEJ. 2012;

20. Tawi, F. B. Kecerdasan Kejayaan Dan Hubungannya Dengan Pencapaian Akademik Pelajar Kejuruteraan Universiti Tun Hussein Onn Malaysia 2008

\section{AUTHORS PROFILE}

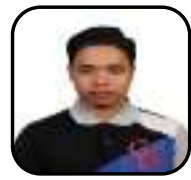

Wan Nasrul Afiq Wan Nazri

Wan Nasrul Afiq is Master student at Universiti Teknologi Malaysia, Malaysia. $\mathrm{He}$ is majoring in Technical and Vocational Education. He acquire Diploma in Mechanical Engineering on 2014 and Degree of Technology with Education in Mechanical Engineering on 2019. He certificated in Air-conditioning and Mechanical Ventilation Level 2 from Construction IndustryDevelopment Board (CIDB).

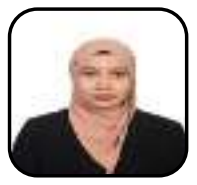

\section{Shafiqah Saidi}

Shafiqah is Master student at Universiti Teknologi Malaysia, Malaysia. She is majoring in Technical and Vocational Education. She acquire Diploma in Mechanical Engineering on 2014 and Degree of Technology with Education in Mechanical Engineering on 2019. She certificated in Air-conditioning and Mechanical Ventilation Level 2 from Construction IndustryDevelopment Board (CIDB).

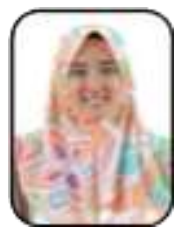

\section{Nur Hazirah Noh@Seth}

Nur Hazirah Noh@Seth is a PhD holder in Mechanical Engineering and currently a researcher and educator in Universiti Teknologi Malaysia. Her contribution in research focuses more on TVET development and topics related to the assessment in TVET.

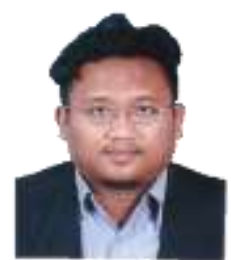

Mohamad Rasidi Pairan

Mohamad Rasidi Pairan is a $\mathrm{PhD}$ holder in Mechanical Engineering and currently a researcher and educator in Universiti Teknologi Malaysia. His contribution in research focuses more on TVET development and topics related to the assessment in TVET.

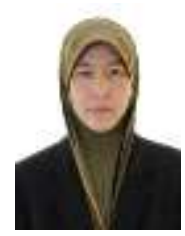

Hanifah Jambari

Hanifah Jambari was born in Johor, Malaysia She received her B.E. (Electrical) degree from Universiti Teknologi Mara Shah Alam, the M. Ed (Technical) and $\mathrm{PhD}$ degrees from Universiti Teknologi Malaysia in 1996, 2001 and 2014 respectively. She is currently a senior lecturer at Department of Technical and Engineering Education, Faculty of Social Sciences and Humanities UTM, Johor. Her research interests include areas of technical and vocational education, engineering education, power electronics and food technology.

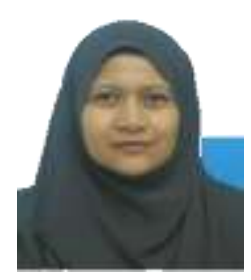

Nurul Aini Mohd Ahyan

Nurul Aini Mohd Ahyan was born in Johor, Malaysia in 1982. She received a bachelor degree in mechanical engineering in 2005 and obtained master degrees in TVET and manufacturing engineering in 2007 and 2012 respectively. In 2017, she completed her Doctor of Philosophy in Mechanical Engineering from Universit Teknologi Malaysia. She is currently a senio lecturer at Department of Technical and Engineering Education, School of Education, Faculty of Social Sciences and Humanities UTM, Johor. Her current research interests include TVET education applied in engineering study, curriculum development and collaborative research. 